\title{
Effect of salinity on physiological and biochemical attributes of different Brinjal (Solanum melongena $\mathrm{L}$.) cultivars
}

\author{
Qasim Ayub ${ }^{1 *}$, Abid Mehmood ${ }^{2}$, Umar Hayat ${ }^{1}$, Qammer Shahzad ${ }^{3}$ and
} Shahzad Ahmad ${ }^{2}$

1. Department of Horticulture, The University of Haripur-Pakistan

2. Department of Agronomy, The University of Haripur-Pakistan

3. Department of Food science and Technology, The University of Haripur-Pakistan

*Corresponding author's email: qasimayub.alizai@gmail.com

Citation

Qasim Ayub, Abid Mehmood, Umar Hayat, QammerShahzad and Shahzad Ahmad. Effect of salinity on physiological and biochemical attributes of different Brinjal (Solanum melongena L.) cultivars. Pure and Applied Biology. Vol. 9, Issue 4, pp2190-2198. http://dx.doi.org/10.19045/bspab.2020.90234

\begin{tabular}{llll}
\hline \hline Received: 13/12/2019 & Revised: 25/02/2020 & Accepted: 30/04/2020 & Online First: 29/05/2020 \\
\hline
\end{tabular}

\section{Abstract}

Current study was conducted at The University of Haripur, to evaluate the effects of salinity on four brinjal cultivars Shamli, Black Nagina, Adventa 306 and Twinkle star. Experiment was laid out in CRD with two factors i.e. brinjal cultivars and salinity levels. Okra cultivars were subjected to four different levels of $\mathrm{NaCl}$ salinity i.e. control, $100 \mathrm{mMol}, 200 \mathrm{mMol}$ and $300 \mathrm{mMol}$. Results revealed that brinjal cultivar Twinkle star exhibits maximum values of Fresh weight $(59 \mathrm{~g})$ and Dry weight $(8.79 \mathrm{~g})$, Plant height $(50.66 \mathrm{~cm})$, Chlorophyll content $(0.032 \mathrm{mg} / \mathrm{g})$, Proline content $(165.08 \mu \mathrm{g} / \mathrm{g})$, and $\mathrm{K}^{+}$ion concentration $(54.8 \mathrm{mg} / \mathrm{g})$, under low to moderate salinity. Hence from this experiment it can be recommended that Twinkle star should be used under saline soil conditions in order to reduce toxic effects of salinity on growth of Brinjal plants.

Keywords: Brinjal; Growth; Salinity; Solanum melongena L; Stress

\section{Introduction}

Brinjal (Solanum melongena L.) belongs to family solanaceae is most common used vegetable in Pakistan due to its unique flavor and high nutritional values. It is commonly known as egg plant due to its similarity with the shape of an egg. It is widely grown on tropic and subtropical parts of the world during summer season [1]. It is noted that about $94 \%$ of the total world production of brinjal comes from Asian continent [2]. Total area of Pakistan under vegetables cultivation is about 385578 ha with production of 3116808 tons, whereas brinjal is cultivated on
8325 ha with 82999 tons annual production. In Punjab, the total cultivated area of brinjal is about 4452 hectares having annual production of 54159 tons [3]. Brinjal exists in variable shapes and color depending on cultivars, i.e. egg shaped, oval and club long shaped with different colors like yellow, green, white, black and purple. Brinjal used as a fresh vegetable but it also possesses tremendous medicinal values and many health benefits [4].

Soil salinity is most common problem faced by farmers which adversely affect almost $20 \%$ of irrigated lands and causes decrease in 
total yield of crops [5]. It is projected that about 800 million hac of land and 32 million hac of cultivated land is being affected by salinity [6]. Many studies have suggested that soil salinity have marked impact on plant morphology and Biochemical reactions of plants like reduction in fresh and dry weight, stunted growth and altered enzymatic activities at cellular level [7]. Saline soils inhibits water uptake by the plants due to osmotic stress created by excess of salt ions in soil which reduces the turgor pressure inside the cell and causes wilting. Another prominent affect of salinity is the gathering of excise toxic ions in root zone, which creates discrepancy of ions and results in ion toxicity, reduction in availability of useful ions and hence causes malnutrition in plants [8]. Some natural solutes present inside the plants enables plants to withstand the toxic effects of salinity, such as accumulation of proline inside plants help them to absorb and scavenge reactive oxygen species [9].

Salt sensitive plants are unable to show proper growth and development when grown in low or moderate saline soils, whereas salt tolerant plants are able to grown and reproduce at high saline soils [8]. In order to prevent harmful effects of salinity, the preservation of the landscape and agriculture fields should be carried out by using environment friendly techniques such as plantation of salt tolerant species. Hence this study is carried out to investigate the effects of $\mathrm{NaCl}$ salinity on physiological and biochemical characteristics of different brinjal cultivars and to select brinjal cultivar which performs best under salinity conditions.

\section{Materials and methods}

Current study was conducted at Department of Horticulture, The University of Haripur during March-May 2019. Experiment was laid out in CRD with two factors (i.e. brinjal verities and salt level)

\section{Plant material and growth conditions}

Seeds of four brinjal cultivars (Shamli, Balck Nagina, Black Boy, Twinkle Star) were obtained from local market. 8 seeds of brinjal were planted in each pot $18 \mathrm{~cm}$ diameter, which were properly filled with potting media (Sand+Soil+FYM). These pots were kept under green house for better protection against environmental conditions. After germination seedlings were thinned to five plants per plant. All cultural practices were carried out regularly throughout the growing period.

\section{Salinity levels}

Brinjal cultivars were treated with four salt levels i.e. $100 \mathrm{mMol}, 200 \mathrm{mMol}, 300 \mathrm{mMol}$, $400 \mathrm{mMol} \mathrm{NaCl}$. Salt treatments were applied after 20 days of germination. Each treatment was replicated four times. After four weeks of salt treatment whole plant from each replication were harvested to obtain the data on different physiological and biochemical parameters.

\section{Physiological parameters}

Data regarding root fresh and dry weight, shoot fresh and dry weight were recorded during the research. Plants were uprooted and washed thoroughly with tap water to remove extra dust and mud. Plants were then weighted for their fresh weight on digital balance. Plant samples were then oven dried for $24 \mathrm{hrs}$ at $60^{\circ} \mathrm{C}$ and then weighted to record dry weight. Mean while for measuring the height of brinjal plants, plants were randomly selected from each replication and the total length of each plant from base to tip was measured with the help of measuring rod.

\section{Biochemical parameters}

Data recording chlorophyll content, electrolyte leakage percentage, proline content, $\mathrm{Na}$ and $\mathrm{K}$ concentration in leaves were recorded.

\section{Chlorophyll content}

Chlorophyll content was determined by extraction of $100 \mathrm{mg}$ seedling sample $5 \mathrm{ml}$ 
$80 \%(\mathrm{v} / \mathrm{v})$ acetone and filtered by using filter paper. Then the filtrate was centrifuges at $5000 \mathrm{rpm}$ for $5 \mathrm{~min}$ and absorbance of supernatant was carried out at 645, 652 and $663 \mathrm{~nm}$ on UV spectrophotometer. Chlorophyll content was calculated by method described by [10].

\section{Proline content}

To calculate proline content, samples from each replication was homogenized by using $3 \%$ sulfosalicylic acid and then the solution was filtered by using filter paper [11]. Ninhydrin and glacial acetic acid was mixed in the filtrate and heated for single hour at $100 \mathrm{C}$ in water bath. The mixture was then absorbed by using tolunen and the absorption of light was measured at $520 \mathrm{~nm}$. Proline concentration was determined by using calibiration curve and expressed in $\mathrm{mg} / \mathrm{g}$.

\section{$\mathrm{Na}^{+}$and $\mathrm{K}^{+}$in leaves}

Plant samples were dried and grounded thoroughly and then mixed in $0.2 \mathrm{~N}$ nitric acid. The mixture was filtered with the help of filter paper and $\mathrm{Na}$ and $\mathrm{K}$ concentrations were determined with the help of flame photometer as describe by the method of [12].

\section{Results and discussions Fresh weight (g)}

Data regarding fresh weight of plant showed that all the verities of brinjal showed significant variation towards salt stress. It was noted that with increase of salt levels the fresh weight of plants decreased. Highest values of shoot fresh weight $(59 \mathrm{~g})$ was noted in Twinkle Star under control conditions where as minimum fresh weight $(18.33 \mathrm{~g})$ were noted in Shamli (Table 1). These results are in line with $[13,14]$ who also reported that an increase in salinity causes reduced plant fresh weight. Salinity is associated with alteration in many traits, which include osmotic stress, specific ion effect, ion imbalances and nutrient deficiency, hence salinity affects many physiological related to plant growth and development [15]. At higher levels of salinity plants shows many physiological affects like in which most stunted growth is most common due to lack of availability of many vital nutrients which are essential for normal plant growth and development. Consequently, accumulation of excessive salt ions can cause death of plant tissues, organs which can cause reduced fresh weight [16].

Table 1. Mean table for Fresh weight (g)

\begin{tabular}{|c|c|c|c|c|c|}
\hline \multirow{2}{*}{ Varity } & \multicolumn{4}{|c|}{ Salt Levels (mMol) } & \multirow{2}{*}{ Means } \\
\cline { 2 - 6 } & control & $\mathbf{1 0 0}$ & $\mathbf{2 0 0}$ & $\mathbf{3 0 0}$ & $27.250 \mathrm{C}$ \\
\hline Shamli V1 & $38.333 \mathrm{E}$ & $30.000 \mathrm{HI}$ & $22.333 \mathrm{~K}$ & $18.333 \mathrm{~L}$ & $37.333 \mathrm{~B}$ \\
\hline Black Nagina V2 & $46.667 \mathrm{C}$ & $46.000 \mathrm{C}$ & $31.000 \mathrm{GH}$ & $25.667 \mathrm{~J}$ & $37.833 \mathrm{~B}$ \\
\hline Adventa-306 V3 & $48.333 \mathrm{C}$ & $40.667 \mathrm{DE}$ & $34.333 \mathrm{~F}$ & $28.000 \mathrm{~J}$ & $46.917 \mathrm{~A}$ \\
\hline Twinkle Star V4 & $59.000 \mathrm{~A}$ & $53.667 \mathrm{~B}$ & $41.667 \mathrm{D}$ & $33.333 \mathrm{FG}$ & \\
\hline Means & $48.083 \mathrm{~A}$ & $42.583 \mathrm{~B}$ & $32.333 \quad \mathrm{C}$ & $26.333 \mathrm{D}$ & \\
\hline
\end{tabular}

\section{Dry weight (g)}

Results related to dry weight of plant showed statistical difference among all treatments and varieties. Maximum dry weight (7.21g) was noted in plants which were treated with tap water whereas minimum dry weight $(4.08 \mathrm{~g})$ was observed in plants which were treated with $300 \mathrm{mMol} \mathrm{NaCl}$ solution. Among different Brinjal cultivars twinkle star produced maximum dry weight $(8.74 \mathrm{~g})$ whereas Shamli produced minimum dry weight (3.41g).Brinjal cultivar Twinkle star produced maximum dry weight $10.16 \mathrm{~g}$, $9.46 \mathrm{~g}, 8.16$ and $7.16 \mathrm{~g}$ under control, 100 $\mathrm{mMol}, 200 \mathrm{mMol}$ and $300 \mathrm{mMol}$ salinity respectively, where as Shamli produced lowest dry weight of $4.0 \mathrm{~g}, 4,3 \mathrm{~g}, 3.1 \mathrm{~g}$ and $2.1 \mathrm{~g}$ at control, $100 \mathrm{mMol}, 200 \mathrm{mMol}$ and 
300 mMol salinity respectively. The interactive effects of salinity over verities showed that increasing salinity levels have imparted a marked reduction in dry weight of all brinjal verities, which are in relevance with the findings of [17] who noted that with increase in salinity brinjal seedlings showed reduced dry matter, and at maximum salinity level lowest values of seedling dry matter were obtained. [18] also obtained similar results and noted that brinjal cultivar Twinkle Star showed maximum dry weight when exposed to different salinity levels. The cultivars which showed minimum reduction in dry weight can be classified as salt tolerant and those which showed maximum reduction can be designated as salt sensitive genotypes. Increase in salinity level decreases the plant dry weight due to less availability of mineral nutrition [19]. Roots of plants are continuously in touch with soils containing toxic salt ions, which hinders in proper growth and development of roots [17] this exposure of root to toxic ions ultimately reduces the biomass production $[20,21]$. Under salinity stress, absorption of $\mathrm{CO}_{2}$ by plant is decreased, as it act as major source of energy for growth, so reduced $\mathrm{CO}_{2}$ levels reduces biomass production (Table 2).

Table 2. Mean table for dry weight (g)

\begin{tabular}{|c|c|c|c|c|c|}
\hline \multirow{2}{*}{ Varity } & \multicolumn{3}{|c|}{ Salt Levels (mMol) } & \multirow{2}{*}{ Means } \\
\cline { 2 - 5 } & Control & $\mathbf{1 0 0}$ & $\mathbf{2 0 0}$ & $\mathbf{3 0 0}$ & \\
\hline Shamli V1 & $4.00 \mathrm{G}$ & $4.33 \mathrm{G}$ & $3.16 \mathrm{H}$ & $2.16 \mathrm{I}$ & $3.41 \mathrm{D}$ \\
\hline Black Nagina V2 & $8.00 \mathrm{C}$ & $7.00 \mathrm{D}$ & $6.00 \mathrm{E}$ & $3.00 \mathrm{H}$ & $6.00 \mathrm{~B}$ \\
\hline Adventa-306 V3 & $7.00 \mathrm{D}$ & $6.00 \mathrm{E}$ & $5.00 \mathrm{~F}$ & $4.00 \mathrm{G}$ & $5.50 \mathrm{C}$ \\
\hline Twinkle Star V4 & $10.16 \mathrm{~A}$ & $9.46 \mathrm{~B}$ & $8.16 \mathrm{C}$ & $7.16 \mathrm{D}$ & $8.74 \mathrm{~A}$ \\
\hline Means & $7.29 \mathrm{~A}$ & $7.70 \mathrm{~B}$ & $5.58 \mathrm{C}$ & $4.08 \mathrm{D}$ & \\
\hline
\end{tabular}

\section{Plant height (cm)}

Results regarding plant height of brinjal cultivars indicate that greatest plant height $(54.41 \mathrm{~cm})$ was obtained in those plants which were treated with tap water where as minimum plant height $(23.58 \mathrm{~cm})$ was seen in $300 \mathrm{mMol}$ salinity. Brinjal cultivar Twinkle star showed highest values of plant height $(50.66 \mathrm{~cm})$ whereas Shamli represented minimum plant height $(24.66 \mathrm{~cm})$. Interaction of salinity and brinjal cultivars showed that highest plant height $(67.66 \mathrm{~cm}, 58.33 \mathrm{~cm}$, $42.33 \mathrm{~cm}$ and $34.33 \mathrm{~cm}$ ) was observed in Twinkle star under control, $100 \mathrm{mMol}, 200$ $\mathrm{mMol}$ and $300 \mathrm{mMol}$ salinity respectively. These results are in accordance with [22] who observed similar reduction in brinjal cultivars when exposed to different levels of salinity. Decline in height can be due to reduced nutrients availably and water transportation to aerial parts of plant, due to impaired and minimum root growth under salinity stress [23]. In many scientific studies it has been proved that growth characteristics like shoot length, height of plants, length of shoots and roots were badly affected by increased salinity levels and plants showed stunted growth. The decreased water potential in saline soils give rise to lower cell turgor values, which causes minimal elongation and division of cell [24]. Vegetative growth of a plant is a key factor which decides the salt sensitivity of plants. It is a proven fact that height of plant is controlled genetically but many environmental factors also control the expression of these genes. Present study clearly demonstrates the said response of genes towards environmental conditions such as salinity. Lower plant height of brinjal plants at higher salinity levels indicates that plants were unable to adjust osmotically to growing conditions, due to which plants failed to uphold required cell growth. 
Salinity also causes dehydration of plants and reduced plant growth indicates failure of dehydration avoidance mechanism hence plants were unable to keep stomatal conductance at suitable rate [25], hence plants didn't holdout against high salinity and exhibited reduced growth [26] (Table 3).

Table 3. Mean table for plant height $(\mathrm{cm})$

\begin{tabular}{|c|c|c|c|c|c|}
\hline \multirow{2}{*}{ Varity } & \multicolumn{4}{|c|}{ Salt Levels (mMol) } & \multirow{2}{*}{ Means } \\
\cline { 2 - 5 } & Control & $\mathbf{1 0 0}$ & $\mathbf{2 0 0}$ & $\mathbf{3 0 0}$ & \\
\hline Shamli V1 & $38.33 \mathrm{~F}$ & $31.66 \mathrm{H}$ & $18.33 \mathrm{~K}$ & $10.33 \mathrm{~L}$ & $24.66 \mathrm{C}$ \\
\hline Black Nagina V2 & $53.33 \mathrm{C}$ & $47.00 \mathrm{D}$ & $34.00 \mathrm{GH}$ & $37.33 \mathrm{I}$ & $40.41 \mathrm{~B}$ \\
\hline Adventa-306 V3 & $58.33 \mathrm{~B}$ & $43.00 \mathrm{E}$ & $35.33 \mathrm{FG}$ & $22.33 \mathrm{~J}$ & $30.75 \mathrm{~B}$ \\
\hline Twinkle Star V4 & $67.66 \mathrm{~A}$ & $58.33 \mathrm{~B}$ & $42.33 \mathrm{E}$ & $34.33 \mathrm{GH}$ & $50.66 \mathrm{~A}$ \\
\hline Means & $54.41 \mathrm{~A}$ & $45.00 \mathrm{~B}$ & $32.50 \mathrm{C}$ & $25.58 \mathrm{D}$ & \\
\hline
\end{tabular}

\section{Chlorophyll Content (mg/g)}

Salinity significantly affected the chlorophyll content of all brinjal cultivars. Highest chlorophyll content $(0.032 \mathrm{mg} / \mathrm{g})$ was noted in brinjal cultivar Twinkle star whereas Shamli showed minimum values of chlorophyll $(0.002 \mathrm{mg} / \mathrm{g})$. Similarly salinity has also reduced chlorophyll content of and maximum reduction in chlorophyll $(0.018 \mathrm{mg} / \mathrm{g})$ was noted at $300 \mathrm{mMol}$ salinity where as minimum reduction in chlorophyll $(0.017 \mathrm{mg} / \mathrm{g})$ was noted in control. The interaction between salinity and brinjal cultivars revel that Twinkle star showed maximum values of chlorophyll i.e. $0.032 \mathrm{mg} / \mathrm{g}, \quad 0.032 \mathrm{mg} / \mathrm{g}, \quad 0.032 \mathrm{mg} / \mathrm{g}$ and $0.031 \mathrm{mg} / \mathrm{g}$ under control, $100 \mathrm{mMol}, 200$ $\mathrm{mMol}$ and $300 \mathrm{mMol}$ salinity respectively, whereas minimum chlorophyll was noted in Shamli i.e. $\quad 0.001 \mathrm{mg} / \mathrm{g}, \quad 0.002 \mathrm{mg} / \mathrm{g}$,
$0.0027 \mathrm{mg} / \mathrm{g}$ and $0.0023 \mathrm{mg} /$ gatcontrol, $100 \mathrm{mMol}, 200 \mathrm{mMol}$ and $300 \mathrm{mMol}$ salinity respectively. The results of our studyarealso in-line with findings of M [27-29] who noted that at higher salinity plants showed minimum chlorophyll contents.Reduced chlorophyll values at elevated salt levels can be due to destruction of chlorophyll pigments and instability of protein complex of green pigments [30]. Higher rate of accumulation of toxic salt ions in leaves discourages the production of proteins responsible for chlorophyll stability [31]. The maximum amounts of chlorophyll in twinkle star can be attributed to the fact that being a salt tolerant cultivar accumulates higher values of ions which increase the chloroplast which intern increases chlorophyll [32] (Table 4).

Table 4. Mean table for chlorophyll content (mg/g)

\begin{tabular}{|c|c|c|c|c|c|}
\hline \multirow{2}{*}{ Varity } & \multicolumn{4}{|c|}{ Salt Levels (mMol) } & \multirow{2}{*}{ Means } \\
\cline { 2 - 5 } & Control & $\mathbf{1 0 0}$ & $\mathbf{2 0 0}$ & $\mathbf{3 0 0}$ & \\
\hline Shamli V1 & $0.0017 \mathrm{~F}$ & $0.0023 \mathrm{~F}$ & $0.0027 \mathrm{~F}$ & $0.0027 \mathrm{~F}$ & $0.0023 \mathrm{D}$ \\
\hline Black Nagina V2 & $0.0117 \mathrm{E}$ & $0.0147 \mathrm{D}$ & $0.0140 \mathrm{D}$ & $0.0147 \mathrm{D}$ & $0.0138 \mathrm{C}$ \\
\hline Adventa-306 V3 & $0.0220 \mathrm{C}$ & $0.0223 \mathrm{BC}$ & $0.0230 \mathrm{BC}$ & $0.0233 \mathrm{~B}$ & $0.0227 \mathrm{~B}$ \\
\hline Twinkle Star V4 & $0.0327 \mathrm{~A}$ & $0.0327 \mathrm{~A}$ & $0.0320 \mathrm{~A}$ & $0.0317 \mathrm{~A}$ & $0.0323 \mathrm{~A}$ \\
\hline Means & $0.0170 \mathrm{~B}$ & $0.0180 \mathrm{~A}$ & $0.0179 \mathrm{~A}$ & $0.0181 \mathrm{~A}$ & \\
\hline
\end{tabular}

\section{Proline content $(\mu \mathrm{g} / \mathrm{g})$}

Data concerning proline content showed significant increase with changing salinity levels. The proline contents of all brinjal genotypes increased significantly by increasing salinity; and maximum increase 
was observed at $300 \mathrm{mMol}$ and gradually decreased by $200 \mathrm{mMol}, 100 \mathrm{mMol}$ and 0 mMol. Maximum values of proline $(165.08 \mu \mathrm{g} / \mathrm{g})$ was noted at $300 \mathrm{mMol}$ salinity whereas minimum (125.67 $\mu \mathrm{g} / \mathrm{g})$ was noted in control treatment. Brinjal cultivar twinkle star exhibits maximum proline content $(229.67 \mu \mathrm{g} / \mathrm{g})$ whereas minimum $(49.58 \mu \mathrm{g} / \mathrm{g})$ was noted in Shamli. The interaction of salinity and verities reveled that Twinkle star produced maximum values of proline i.e. $205.00 \mu \mathrm{g} / \mathrm{g}$, $226.67 \mu \mathrm{g} / \mathrm{g}, \quad 236.67 \mu \mathrm{g} / \mathrm{g}$ and $250.33 \mu \mathrm{g} / \mathrm{g}$ when exposed to control, $100 \mathrm{mMol}, 200$ $\mathrm{mMol}$ and $300 \mathrm{mMol}$ salinity respectively, whereas minimum proline i.e. $40.00 \mu \mathrm{g} / \mathrm{g}$, $56.67 \mu \mathrm{g} / \mathrm{g}, 46.67 \mu \mathrm{g} / \mathrm{g}$ and $55.00 \mu \mathrm{g} / \mathrm{g}$ was noted in Shamli when exposed to control, 100mMol, $200 \mathrm{mMol}$ and $300 \mathrm{mMol}$ salinity respectively. These findings are also in accordance with the work of [33] who reported similar increase in proline content of different brinjal cultivars when exposed to elevated salinity level.Salinity causes an ionic imbalance which results an oxidative stress. Fabrication of reactive oxygen species (ROS) is a sign of oxidative stress. Superoxide radical initiates a series of reactions that generates ROS, which interrupts the metabolic process of cell by oxidative degradation of nucleic acids, proteins and lipids [34]. The accumulation of osmolytes like proline is a common defense strategy of plants against different stress especially salinity stress. Proline under saline condition acts as ROS scavenger, energy supplier and function as signal. Proline accumulation in leaves also help to maintain chlorophyll level and cell turgor pressure which protects the photosynthesis activity of plants [35] (Table $5)$.

Table 5. Mean table for proline content $(\mu \mathrm{g} / \mathrm{g})$

\begin{tabular}{|c|c|c|c|c|c|}
\hline \multirow{2}{*}{ Varity } & \multicolumn{4}{|c|}{ Salt Levels (mMol) } & \multirow{2}{*}{ Means } \\
\hline & Control & 100 & 200 & 300 & \\
\hline Shamli V1 & $40.00 \mathrm{~L}$ & $56.67 \mathrm{~J}$ & $46.67 \mathrm{KI}$ & $55.00 \mathrm{JK}$ & $49.58 \mathrm{D}$ \\
\hline Black Nagina V2 & $121.00 \mathrm{I}$ & $175.00 \mathrm{EF}$ & $156.67 \mathrm{G}$ & $173.33 \mathrm{EF}$ & $156.50 \mathrm{C}$ \\
\hline Adventa-306 V3 & $136.67 \mathrm{H}$ & $175.00 \mathrm{EF}$ & $168.33 \mathrm{~F}$ & $141.67 \mathrm{E}$ & $165.42 \mathrm{~B}$ \\
\hline Twinkle Star V4 & $205.00 \mathrm{D}$ & $226.67 \mathrm{C}$ & $236.67 \mathrm{~B}$ & $250.33 \mathrm{~A}$ & $229.67 \mathrm{~A}$ \\
\hline Means & $125.67 \mathrm{D}$ & $158.33 \mathrm{~B}$ & $152.08 \mathrm{C}$ & $165.08 \mathrm{~A}$ & \\
\hline
\end{tabular}

\section{$\mathrm{Na}^{+}$Ion concentration in leaves $(\mathrm{mg} / \mathrm{g})$}

Results of current study revels increased amounts of $\mathrm{Na}^{+}$Ion at higher levels of salinity i.e. 100,200 and $300 \mathrm{mMol}$ salinity. Maximum $\mathrm{Na}^{+}$Ion concentration (71.75 $\mathrm{mg} / \mathrm{g}$ ) was obtained in those plants which were treated with $300 \mathrm{mMol} \mathrm{NaCl}$ solution. Brinjal cultivar Shamli exhibits the highest amounts of $\mathrm{Na}^{+}$Ion $(91.33 \mathrm{mg} / \mathrm{g})$ whereas Twinkle star showed minimum $\mathrm{Na}^{+}$ Ionconcentration $\quad(25.91 \mathrm{mg} / \mathrm{g})$. Data concerning interaction of variety and salinity revels that salt sensitive Shamli showed maximum $\mathrm{Na}^{+}$Ion of 98.33, 92.00, 86.66 and $88.33 \mathrm{mg} / \mathrm{g}$ when treatedwith control, 100mMol, $200 \mathrm{mMol}$ and 300
mMol salinity respectively, whereas salt tolerant cultivar showed minimum (28.33, $29.33,23.00,29.33 \mathrm{mg} / \mathrm{g}) \mathrm{Na}^{+}$Ion concentration atcontrol, $100 \mathrm{mMol}, 200$ $\mathrm{mMol}$ and $300 \mathrm{mMol}$ salinity respectively. These results are also supported by the findings of [33] who observed that elevated salt concentration in soil increases the $\mathrm{Na}^{+}$ Ion in leaves of egg plant. $\mathrm{Na}^{+}$Ion accumulation is common phenomenon in plants under saline conditions. Salinity stresscauses a significant effect on a variety of ionic qualities. It was observed that salinity stress elevates $\mathrm{Na}+$ ion concentration in leaves. Brinjal cultivars showed significant difference between ionic 
attributes. Twinkle star showed lowest amounts of Na ions as compared to Shamli, which indicated the adoptability of twinkle star toward saline conditions. Plants which are tolerant to salinity have lowest amounts of $\mathrm{Na}$ ions by mechanism of deposition of toxic ions in roots and leaves [36] (Table 6).

Table 6. Mean table for $\mathrm{Na}^{+}$concentration in leaves $(\mathrm{mg} / \mathrm{g})$

\begin{tabular}{|c|c|c|c|c|c|}
\hline \multirow{2}{*}{ Varity } & \multicolumn{4}{|c|}{ Salt Levels (mMol) } & \multirow{2}{*}{ Means } \\
\cline { 2 - 5 } & control & $\mathbf{1 0 0}$ & $\mathbf{2 0 0}$ & $\mathbf{3 0 0}$ & \\
\hline Shamli V1 & $88.33 \mathrm{BC}$ & $86.66 \mathrm{BC}$ & $92.00 \mathrm{AB}$ & $98.33 \mathrm{~A}$ & $91.33 \mathrm{~A}$ \\
\hline Black Nagina V2 & $71.66 \mathrm{FG}$ & $81.66 \mathrm{CDE}$ & $77.00 \mathrm{EFG}$ & $81.33 \mathrm{CDE}$ & $77.91 \mathrm{~B}$ \\
\hline Adventa-306 V3 & $75.00 \mathrm{EFG}$ & $85.00 \mathrm{BCD}$ & $70.66 \mathrm{G}$ & $79.00 \mathrm{DEF}$ & $77.41 \mathrm{D}$ \\
\hline Twinkle Star V4 & $29.33 \mathrm{H}$ & $23.00 \mathrm{H}$ & $23.00 \mathrm{H}$ & $28.33 \mathrm{H}$ & $25.91 \mathrm{C}$ \\
\hline Means & $66.09 \mathrm{~B}$ & $69.08 \mathrm{AB}$ & $65.66 \mathrm{~B}$ & $71.75 \mathrm{~A}$ & \\
\hline
\end{tabular}

\section{$\mathrm{K}^{+}$Ion Concentration in Leaves $(\mathbf{m g} / \mathrm{g})$}

Data concerning amounts of $\mathrm{K}^{+}$Ions in leaves indicates that with increase of salinity a decrease in $\mathrm{K}^{+}$Ions occurs.Maximum amounts of $\mathrm{K}^{+}$Ions $(54.83 \mathrm{mg} / \mathrm{g})$ were observed in control whereas minimum $\mathrm{K}^{+}$ Ions $(19.58 \mathrm{mg} / \mathrm{g})$ was observed at $300 \mathrm{mMol}$ salinity. Similarly maximum $\mathrm{K}^{+}$Ion concentration $(41.50 \mathrm{mg} / \mathrm{g})$ was noted in Twinkle star whereas minimum $(37.58 \mathrm{mg} / \mathrm{g})$ was seen in Black Nagina. The combine effect of salinity and verity showed that maximum $\mathrm{K}^{+}$Ion concentration (55.00, $47.66,38.00$ and $18.00 \mathrm{mg} / \mathrm{g}$ ) was observed in Twinkle star. These results indicate that with increasing levels of salinity $\mathrm{K}^{+}$Ion concentration decreases dramatically. Outcomes of current experiment were similar to those of $[33,36,37]$. All brinjal cultivars exhibits lower values of $\mathrm{K}$ ion in leaves except salt tolerant cultivar Twinkle star which showed maximum $\mathrm{K}$ ions. Under salinity stress an antagonistic effect establish between toxic Na ion and useful ions. [20], due to this effect accumulation of $\mathrm{Na}$ ions render the entry of other useful ions in plants from soil solution which results in drop of $\mathrm{K}$ ions in plants (Table 7).

Table 7. Mean table for $\mathrm{K}^{+}$ion concentration in leaves $(\mathrm{mg} / \mathrm{g})$

\begin{tabular}{|c|c|c|c|c|c|}
\hline \multirow{2}{*}{ Varity } & \multicolumn{4}{|c|}{ Salt Levels (mMol) } & \multirow{2}{*}{ Means } \\
\cline { 2 - 5 } & control & $\mathbf{1 0 0}$ & $\mathbf{2 0 0}$ & $\mathbf{3 0 0}$ & \\
\hline Shamli V1 & $66.00 \mathrm{~A}$ & $48.00 \mathrm{C}$ & $33.00 \mathrm{E}$ & $25.00 \mathrm{~F}$ & $41.50 \mathrm{~A}$ \\
\hline Black Nagina V2 & $51.66 \mathrm{~B}$ & $46.33 \mathrm{C}$ & $35.33 \mathrm{DE}$ & $17.00 \mathrm{G}$ & $37.58 \mathrm{C}$ \\
\hline Adventa-306 V3 & $52.66 \mathrm{~B}$ & $47.66 \mathrm{C}$ & $37.00 \mathrm{D}$ & $18.00 \mathrm{G}$ & $38.83 \mathrm{BC}$ \\
\hline Twinkle Star V4 & $55.00 \mathrm{~B}$ & $47.66 \mathrm{C}$ & $38.00 \mathrm{D}$ & $18.33 \mathrm{G}$ & $39.75 \mathrm{AB}$ \\
\hline Means & $54.83 \mathrm{~A}$ & $47.41 \mathrm{~B}$ & $35.88 \mathrm{C}$ & $19.58 \mathrm{D}$ & \\
\hline
\end{tabular}

\section{Conclusions and recommendations}

From this experiment it is concluded that Salinity has caused prominent effects on all brinjal cultivars. Among different salt levels 200 and $300 \mathrm{mMol}$ salinity have caused a marked reduction in all physiological and morphological parameters of brinjal. Brinjal cultivar Twinkle star showed minimum reduction in all studied parameters and successfully tolerated the harmful effects of salinity. Shamli showed maximum reduction in all studies parameters and hence failed to develop any defense against applied salt stress. Hence from this experiment it can be recommended that farmers should grow Twinkle star under saline soil conditions to obtain maximum growth and to prevent economic losses caused by salinity. 


\section{Authors' contributions}

Conceived and designed the experiments: $Q$ Ayub \& A Mehmood, Performed the experiments: Q Ayub \& U Hayat, Analyzed the data: Q Shahzad \& S Ahmed, Contributed materials/ analysis/ tools: U Hayat \& Q Shahzad, Wrote the paper: Q Ayub \& A Mehmood.

\section{References}

1. Waqas MS, Aqueel MA, Afzal M, Raza ABM, Kamran M, Mustafa I \& Bakar MA (2014). Influence of temperature on the seasonal abundance of predatory mites Euseius scutalis in few cotton cultivars. Int J Agric Appl Sci 6(1): 89-96

2. Abbas W, Ashraf M \& Akram NA (2010). Alleviation of salt-induced adverse effects in eggplant (Solanum melongena L.) by glycine-betaine and sugar beet extracts. Sci Hortic 125(3): 188-195.

3. Akinci IE, Akinci S, Yilmaz K \& Dikici H (2004). Response of eggplant varieties (Solanum melongena) to salinity in germination and seedling stages. New Zeal J Crop Hort 32(2): 193-200.

4. Pugalendhi L, Veeraragavathatham D, Natarjan S \& Praneetha S (2010). Utilizing wild relative (Solanum viarum) as resistant source to shoot and fruit borer in brinjal (Solanum melongena Linn.). Electron. J Plant Breed 1(4): 643-648.

5. Negrão S, Schmöckel SM \& Tester M (2017). Evaluating physiological responses of plants to salinity stress. Ann Bot 119(1): $1-11$.

6. Wichelns D \& Qadir M (2015). Achieving sustainable irrigation requires effective management of salts, soil salinity, and shallow groundwater. Agric Water Manag 157(2): 31-38.

7. Chartzoulakis K \& Klapaki G (2000). Response of two greenhouse pepper hybrids to $\mathrm{NaCl}$ salinity during different growth stages. Sci Hortic 86(3): 247-260.

8. Munns R \& Tester M (2008). Mechanisms of salinity tolerance. Annu Rev Plant Biol 59(3): 651-681.
9. Qureshi MI, Abdin MZ, Ahmad J \& Iqbal M (2013). Effect of long-term salinity on cellular antioxidants, compatible solute and fatty acid profile of Sweet Annie (Artemisia annua L.). Phytochem 95(1): 215-223.

10. Munns R \& Tester M (2008). Mechanisms of salinity tolerance. Annu Rev Plant Biol 59(1): 651-681.

11. Nayyar H (2003). Accumulation of osmolytes and osmotic adjustment in water-stressed wheat (Triticum aestivum) and maize (Zea mays) as affected by calcium and its antagonists. Environ Exp Bot 50(3): 253-264.

12. Bates LS, Waldren RP \& Teare ID (1973). Rapid determination of free proline for water-stress studies. Plant Soil 39(1): 205207.

13. Ashraf M \& Rauf H (2001). Inducing salt tolerance in maize (Zea mays L.) through seed priming with chloride salts: Growth and ion transport at early growth stages. Acta Acta Physiol. Plant 23(4): 407-414.

14. Uddina AJ, Mutaheraa S, Mehrajb H, Momenac K \& Nahiyanc ASM (2016). Screening of brinjal lines to high salinity levels. J Biosci Agric Res 7(2): 630-637.

15. Ayub Q, Khan SM, Hussain AKI, Ahmad Z \& Khan MA (2018). Effect of gibberellic acid and potassium silicate on physiological growth of Okra (Abelmoschus esculentus L.) under salinity stress. Pure Appl Biol 7(1): 8-19.

16. Munns R, James RA \& Läuchli A (2006). Approaches to increasing the salt tolerance of wheat and other cereals. J Exp Bot 57(5): 1025-1043.

17. Munns R \& Termaat A (1986). Wholeplant responses to salinity. Funct Plant Biol 13(1): 143-160.

18. Sá FDS, Souto LS, Paiva ED, Araújo EB, Oliveira FD, Mesquita ED \& Dantas JS (2017). Initial development and tolerance of bell pepper (Capsicum annuum) cultivars under salt stress. $J$ Agric Sci 9(11): 181-189. 
19. Irulappan I (1993). Screening of brinjal (Solanum melongena L.) genotypes for salinity tolerance. South Indian $J$ Hortic 41(5): 14-14.

20. Kiremit MS \& Arslan H (2016). Effects of irrigation water salinity on drainage water salinity, evapotranspiration and other leek (Allium porrum L.) plant parameters. Sci Horti 201(9): 211-217.

21. Shahbaz M, Ashraf M, Al-Qurainy F \& Harris PJ (2012). Salt tolerance in selected vegetable crops. Crit Rev Plant Sci 31(4): 303-320.

22. Gao X, Zou C, Wang L \& Zhang F (2006). Silicon decreases transpiration rate and conductance from stomata of maize plants. J Plant Nutr 29(9): 1637-1647.

23. Greenway H \& Munns R (1980). Mechanisms of salt tolerance in nonhalophytes. Annu Rev Plant Physiol 31(1): 149-190.

24. Abbruzzese G, Beritognolo I, Muleo R, Piazzai M, Sabatti M, Mugnozza GS \& Kuzminsky E (2009). Leaf morphological plasticity and stomatal conductance in three Populus alba L. genotypes subjected to salt stress. Environ Exp 66(3): 381-388.

25. Tyerman SD \& Skerrett IM (1998). Root ion channels and salinity. Sci Horti 78(4): 175-235.

26. Syvertsen JP, Lee LS \& Grosser JW (2000). Limitations on growth and net gas exchange of diploid and tetraploid Citrus rootstock cultivars grown at elevated CO2. J Am Soc Hortic Sci 125(2): 228234.

27. Arnon DI (1949). Copper enzymes in isolated chloroplasts. Polyphenoloxidase in Beta vulgaris. Plant Physiol 24(1): 1-15.

28. Hameed A, Sheikh MA, Jamil A \& Basra SMA (2013). Seed priming with sodium silicate enhances seed germination and seedling growth in wheat (Triticum aestivum L.) under water deficit stress induced by polyethylene glycol. Pak J Life Soc Sci 11(1): 19-24.

29. Irulappan I (1993). Screening of brinjal (Solanum melongena L.) genotypes for salinity tolerance. Indian J Hortic 41(6): 14-14.

30. Zhu JK (2001). Cell signaling under salt, water and cold stresses. Curr Opin Plant Biol 4(5): 401-406.

31. Jaleel CA, Manivannan P, Lakshmanan GMA, Sridharan R \& Panneerselvam R (2007). $\mathrm{NaCl}$ as a physiological modulator of proline metabolism and antioxidant potential in Phyllanthus amarus. $C R$ Biol 330(11): 806-813.

32. Misra AN, Sahu SM, Misra M, Singh P, Meera I, Das N \& Sahu P (1997). Sodium chloride induced changes in leaf growth, and pigment and protein contents in two rice cultivars. Biol Plant 39(2): 257-262.

33. Mustafa Z, Ayyub CM, Amjad M \& Ahmad R (2017). Assesment of biochemical and ionic attributes against salt stress in eggplant (Solanum melongena L.) genotypes. JAPS: J of Animal \& Plant Sci 27(2): 503-509.

34. Munns R \& Tester M (2008). Mechanisms of salinity tolerance. Annu Rev Plant Biol 59(1): 651-681.

35. Sharma S, Villamor JG \& Verslues PE (2011). Essential role of tissue-specific proline synthesis and catabolism in growth and redox balance at low water potential. Plant Physiol 157(1): 292-304.

36. Shaheen $S$, Naseer $S$, Ashraf M \& Akram NA (2013). Salt stress affects water relations, photosynthesis, and oxidative defense mechanisms in Solanum melongena L. J Plant Interact 8(1): 85-96.

37. Elwan MW (2010). Ameliorative effects of di-potassium hydrogen orthophosphate on salt-stressed eggplant. J Plant Nutr 33(11): 1593-1604. 